\title{
The Global Experience of Deployment of Energy- Efficient Technologies in High-Rise Construction
}

\author{
Natalia D. Potienko ${ }^{1, *}$, Anna A. Kuznetsova ${ }^{1}$, Darya N. Solyakova ${ }^{1}$, and Yulia E. Klyueva ${ }^{1}$ \\ ${ }^{1}$ Samara State Technical University, 443001, Samara, Molodogvardeyskaya st, 194, Russia
}

\begin{abstract}
The objective of this research is to examine issues related to the increasing importance of energy-efficient technologies in high-rise construction. The aim of the paper is to investigate modern approaches to building design that involve implementation of various energy-saving technologies in diverse climates and at different structural levels, including the levels of urban development, functionality, planning, construction and engineering. The research methodology is based on the comprehensive analysis of the advanced global expertise in the design and construction of energy-efficient high-rise buildings, with the examination of their positive and negative features. The research also defines the basic principles of energy-efficient architecture. Besides, it draws parallels between the climate characteristics of countries that lead in the field of energy-efficient high-rise construction, on the one hand, and the climate in Russia, on the other, which makes it possible to use the vast experience of many countries, wholly or partially. The paper also gives an analytical review of the results arrived at by implementing energy efficiency principles into high-rise architecture. The study findings determine the impact of energy-efficient technologies on high-rise architecture and planning solutions. In conclusion, the research states that, apart from aesthetic and compositional interpretation of architectural forms, an architect nowadays has to address the task of finding a synthesis between technological and architectural solutions, which requires knowledge of advanced technologies. The study findings reveal that the implementation of modern energy-efficient technologies into high-rise construction is of immediate interest and is sure to bring long-term benefits.
\end{abstract}

\section{Introduction}

Rapid industrial development alongside with urban sprawl that led to a high urban population density has prompted the grand-scale construction first of multistory, and then of high-rise buildings. In the early stages of its development high-rise construction was primarily focused on the problems of structural design, space planning, massing and engineering, but later on a great number of prominent architects turned to extensive research on structural morphology $[1,2]$. This led to the establishment of the International Style, as well as to the formation of various conceptions concerning the location of high-rises in the layout of American, European and Asian cities. There emerged a necessity to introduce new massing solutions in order to make monotonous residential areas more varied and resident

*Corresponding author: natalia.potienko@mail.ru 
friendly, which in its turn gave rise to the new types of spectacular and eye-catching highrise buildings (Petronas Towers, Burj al-Arab, Burj Khalifa, Taipei 101, etc.).

The 1974 and 1992 energy crises caused the shifting of emphasis in the sphere of building design, with high-rise design being no exception. The first steps were to make the best use of such architectural techniques as the orientation of a building along the cardinal directions and to the prevailing winds, and the application of different types of façade glazing: maximum on the south side and minimal on the north. These passive methods depend upon the climate of a certain region and are characterized by low energy consumption. However, the very attitude towards the usage of energy was reconsidered later on. This problem is covered in a considerable number of research studies [3-22]. Today the energy policies of all countries in the world are aimed at designing energy-efficient and comfortable buildings through the implementation of efficient architectural and technical solutions. The resiliency of a building is improved by harnessing alternative energy sources - solar and wind energy, geothermal energy and hydropower, as well as by the conservation of natural resources and the application of modern technologies (intelligent systems). All this results in the transformation of exterior design and makes it necessary to reconsider the traditional functional, planning, design and engineering structures of a building.

\section{Materials and Methods}

It should be noted that the grand-scale construction of energy-efficient high-rise buildings is carried out worldwide. The USA along with a number of Asian countries and the UAE are considered to be the world's leading nations in the sphere of high-rise construction. The climates of the abovementioned countries comprise a wide range of weather conditions, which influence the implementation of certain energy-efficient technologies in different ways. Many experts claim that the methodology of energy-efficient high-rise design should be based on a systematic and comprehensive analysis of a building as a unified energy system. Nowadays the reduction of energy consumption and a negative environmental impact has become one of the ways to improve the comfort level of a building. From this perspective, various energy-saving methods and techniques are employed around the world to improve the energy performance of high-rise buildings and complexes. These methods rely not only on the use of modern engineering systems, but also on the implementation of efficient space planning, architectural and design solutions.

Due to the vastness of its territory, Russia is located in four climatic zones: arctic, subarctic, temperate and subtropical. The temperate zone occupies the largest part of the country, while only a small portion of the Black Sea coast, namely the Caucasus Riviera and Crimea, possesses a subtropical climate. As a consequence, significant weather contrasts can be observed in the country. For instance, the average temperature of the warmest month ranges from $+1{ }^{\circ} \mathrm{C}$ in the Far North to $+25{ }^{\circ} \mathrm{C}$ in the Caspian Depression and $+40{ }^{\circ} \mathrm{C}$ in the south-west of Siberia. The same pattern is witnessed in the temperature of the coldest month - from $+6{ }^{\circ} \mathrm{C}$ on the Black Sea coast to $-50{ }^{\circ} \mathrm{C}$ in north-eastern Siberia. Many factors influence the shape of a building, hence its natural lighting, ventilation and thermal efficiency. Solar activity, for one. Also, the prevailing winds and wind force, the amount and pattern of precipitation, as well as mistiness and air humidity.

The concept of energy-efficiency has finally started to gain recognition in Russia. Many Russian companies, both those who construct and those who use buildings, have come to understand that there exists an acute problem of heat loss and that it is necessary to implement the most advanced energy-saving solutions and modern thermal protection materials, sandwich wall constructions, energy-saving plumbing systems and engineering equipment into high-rise construction. Moreover, the country is witnessing significant changes in the legislative and regulatory frameworks. A bill has been passed recently to increase the share 
of nonconventional and renewable energy sources up to 10 per cent. Besides, documents were developed providing for regulations concerning the implementation of energy-efficient technologies in Russia. In this regard, it is of vital importance to examine and analyze the global expertise in the use of energy-efficient technologies in order to apply it in high-rise construction and adjust it to the Russian climate, as well as to develop our own unique solutions.

\section{Results}

The research offers an analytical review of the results arrived at by implementing the principles of energy-efficient architecture.

The Pearl River Tower (310 m, 71 stories, 2013) is considered to be the first genuinely green skyscraper in China. The tower is also known as the most sustainable building in the Middle Kingdom (figure 1a). The building was deliberately oriented along the cardinal directions and to the prevailing winds [23].
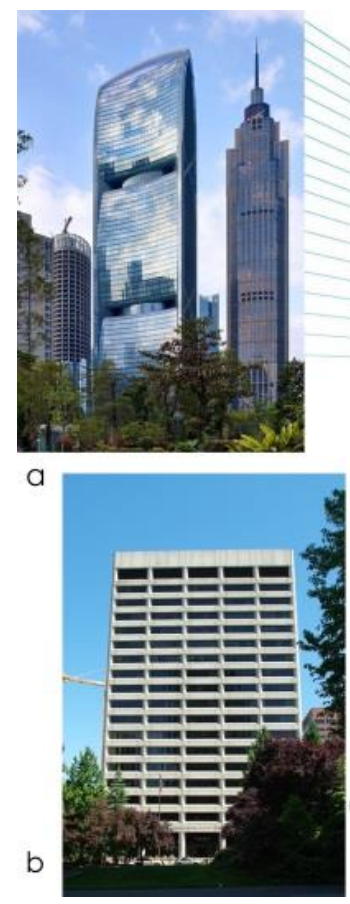

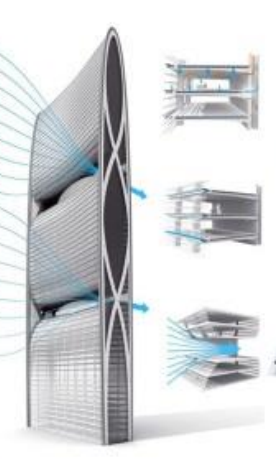

COOUNG TOWER MAKEUP WATER
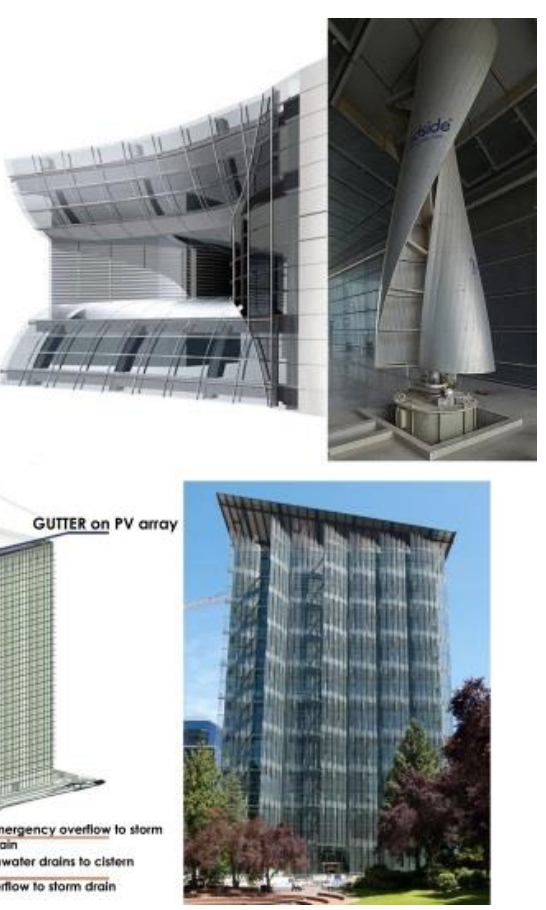

Fig. 1. Examples of buildings: a - Pearl River Tower, an administrative office centre, Guangzhou, China. Authors: Adrian Smith + SOM [23], b - Edith Green-Wendell Wyatt Federal Building, an office building, Portland, USA. Authors: Skidmore, Owings and Merrill [24].

The tower's triple-glazed façade blocks external heat, thus eliminating the need for air cooling. Lighting control sensors and mechanized blinds are programmed to maximize natural lighting. The south façade has three main structural parts formed by glass panels curved both vertically and horizontally. The façade is shaped so that air masses can accumulate in the cavities between the parts. Convex glass panels acting as deflectors are located in the middle of the cavities. Air masses hit the surface of the deflector and move into air inlets where wind turbines are located. The Pearl River Tower design uses some elements of the exterior enclosure as a surface for accumulation and deflection. Besides, the enclosure also functions as a part of the building`s wind turbine system, which characterizes it as a 
polyfunctional element. The tower owes its unique shape to the synthesis of design, material and technological solutions. Another innovative aspect of the building`s design was the use of wind mills: four wind turbines with $6 \mathrm{~m}$ diameter impellers are incorporated into the openings of the mechanical floor enclosures - two mills in each mechanical floor. Furthermore, the building's power supply relies on the use of photovoltaic panels integrated into the east and west façades. The most notable energy savings are achieved via cooling ceiling systems, which are remarkable for using water instead of air. In order to prevent condensation the incoming air is dehumidified in special heat transfer apparatuses located in the mechanical floors. Fresh air is provided via the system of displacement ventilation integrated into the floor construction. Another notable feature is that air ventilation between the glass panels of the façade constitutes a part of the overall aerodynamic system of the building.

The Edith Green-Wendell Wyatt Federal Building (110 m, 18 stories, (1974) - 2013) is a high-rise structure completed in the 1970s and transformed into a sustainable tower in the course of a three-year renovation project (figure 1b). A new glass and metal enclosure completely changed the appearance of this modernist looking concrete parallelepiped [24].

The building`s façades were tuned to respond to the unique solar exposure of each side. The reed-like shades affixed to the west façade of the building provide 50 percent shading on the west side, where the sun is low and light comes in at a small angle. The 'reeds' have a trapezoidal cross section, the narrow part of which faces the interior. This was done in order to optimize shading and to reduce both the size of 'reeds' and the total weight of the construction. The round edges of the 'reeds' do not produce sharp shadows. The south and east façades are equipped with both horizontal and vertical shading systems with a depth of $60 \mathrm{~cm}$. While the bottom part of the horizontal shelves casts a slight downward shadow, the upper part bounces daylight 9-10.5 m toward the interior spaces, thus making the most of natural light. Apart from optimizing the building`s solar exposure, these structures also help to reduce cooling costs.

Two layers of insulation, each $10 \mathrm{~cm}$ wide, were incorporated into window sill panels to protect the building`s envelope from heat loss. Air circulation is provided via the dual system of radiant heating and cooling reinstalled above the drop ceiling. Greater than 65 percent water savings were made possible due to implementing water conserving plumbing fixtures together with a rainwater system. A 770-liter tank allows rainwater to be stored and used for technical purposes such as toilet flushing, irrigation and cooling. The single-pitched roof of the building supports a 180 photovoltaic panel that ensures additional energy savings (4-15 percent). Another aspect of the 'green modernization' is the use of energy-efficient elevators with regenerative drives that restore potential energy when the carriage travels down.

The Al Bahar Towers (145 m, 29 stories, 2012) is a high-rise structure consisting of two towers that use the motifs of traditional architecture on their façades (figure 2a). In order to protect the interior spaces from 50 degrees Celsius heat, the design team installed a shading system above the building`s façade on the south, east and west sides. This screening system comprises 2000 umbrella-like components that open and close in response to the sun's path and external lighting conditions $[25,26]$. The shading units are controlled via the building management system so that the devices are fully open in the morning and fully closed at noon. The system runs on renewable energy generated by photovoltaic panels that are located on the southward sloping roofs of the towers. The protective screen helps to maintain a comfortable room temperature and eliminates the building's need for air-conditioning, which significantly reduces energy consumption. It also ensures indoor air ventilation and reduces the need for artificial lighting. The glass used for the façade glazing was slightly tinted in order to improve the comfort level for office workers and enhance the protective effect. The building design is a perfect example of how modern technologies can be integrated with ancient Arabic traditions that let local people survive extreme weather conditions. 

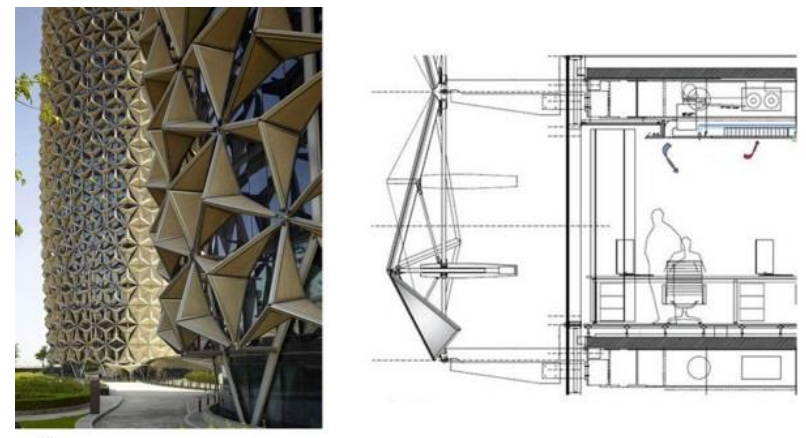

a

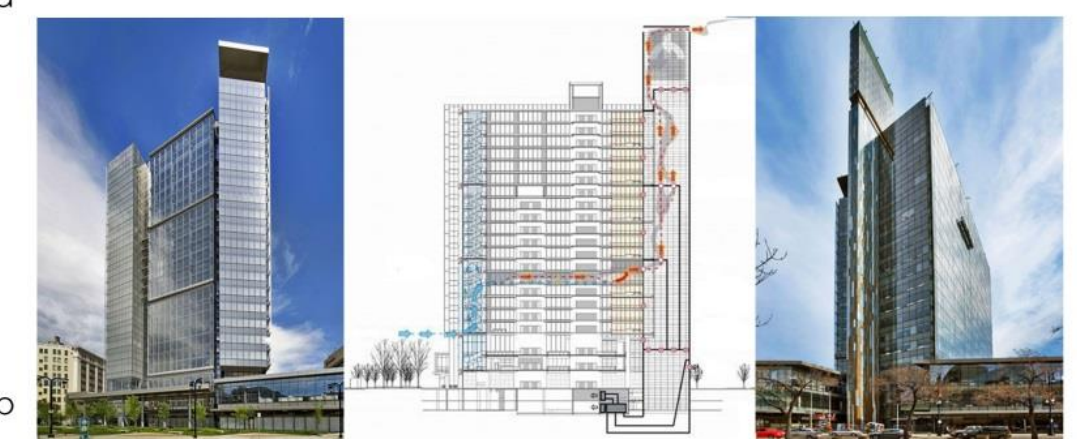

Fig. 2. Examples of buildings: a - Al Bahar Towers, an administrative office centre, Abu-Dhabi, UAE. Authors: Aedas Architects Ltd [25, 26], b - Manitoba Hydro Place, an office centre, Winnipeg, Canada. Authors: KPMB Architects with Smith Carter Architects [27].

Manitoba Hydro Place (115 m, 22 stories, 2008) is a building, the architectural form, orientation and size of which take into account Winnipeg`s harsh continental climate (figure 2b). A 115-meter tall solar chimney makes the main entrance and is rotated to position the multilevel atria southward, thus allowing solar radiation and wind energy to be used during winter [27]. The tower itself functions as a passive solar collector which relies on the natural stack effect. In winter, exhaust air is drawn to the bottom of the solar chimney by fans. The recovered heat is then used to warm the parkade and to preheat the incoming cold air in the south arcade. During summer months used air is drawn out of the building. East and west oriented office spaces are splayed southward, which significantly reduces heat loss. Floorto-ceiling windows and narrow floor plates maximize natural lighting. Among other functions, winter gardens located on the south side pre-condition the incoming air, while an artificial waterfall provides humidification. A green roof supports plants and harnesses rainwater. The active systems of the building include light-regulating, computer-controlled and energy-saving fluorescent lamps. The reduction in heating demand for the building is largely due to a double façade on the west, east and south sides. In summer, operable windows on the outer (double-glazed) façade open and allow wind and convective air flows to ventilate the double façade. Mechanized window blinds control heat gain, while exterior blinds are manually operable and can be open for the purpose of air ventilation. Thus, the façade contributes to reducing thermal load. Heating and cooling is achieved primarily through the use of active radiant slabs (more than $290000 \mathrm{~m}$ of plastic tubing is embedded in the concrete). Besides, the building also harnesses the internal heat of its geothermal system. The massive all-concrete building reduces temperature fluctuations through the occupied hours and allows heating and cooling systems to be turned off in the evenings and at weekends. Two on-site weather stations collect climate data (temperature, solar radiation, wind velocity 
and direction, rainfall intensity) and use it to optimize the performance of engineering equipment (operable windows, the angle of the shading devices, slab temperatures, etc.).

The Bosco Verticale (115.9 m, 30 stories, 2008-2014) consists of two residential towers, 80 and 112 meters high respectively (figure $3 \mathrm{a}$ ). The façades are covered with plants which vary in form and size and provide dust absorption, solar protection and a favourable microclimate [28, 29]. This building can be considered a kind of biological architecture which refuses to take a strictly technological and mechanical approach to environmental sustainability. Both towers are oriented exactly along the cardinal directions. Due to their compact layout, the towers minimize heat loss during the cold period. A special kind of soil was selected in order to reduce the structural load of the cast-in-place reinforced concrete building. On the one hand, the soil is not very heavy. On the other, it meets the nutritional requirements of the plants. Experimental tests performed in a wind tunnel showed that the plants did not add to the overall wind load on the building. Centralized automatic drip irrigation is provided via a system of water storage and treatment which collects and filters grey water and rainwater. Photovoltaic panels and solar collectors provide the towers with power and hot water supply, while geothermal energy is exploited for heating.

The building of the Strata Tower (147.9 m, 44 stories, 2005-2010) is oriented along the cardinal directions and to the prevailing winds so as to maximize the use of daylight and south wind (figure $3 b$ ).
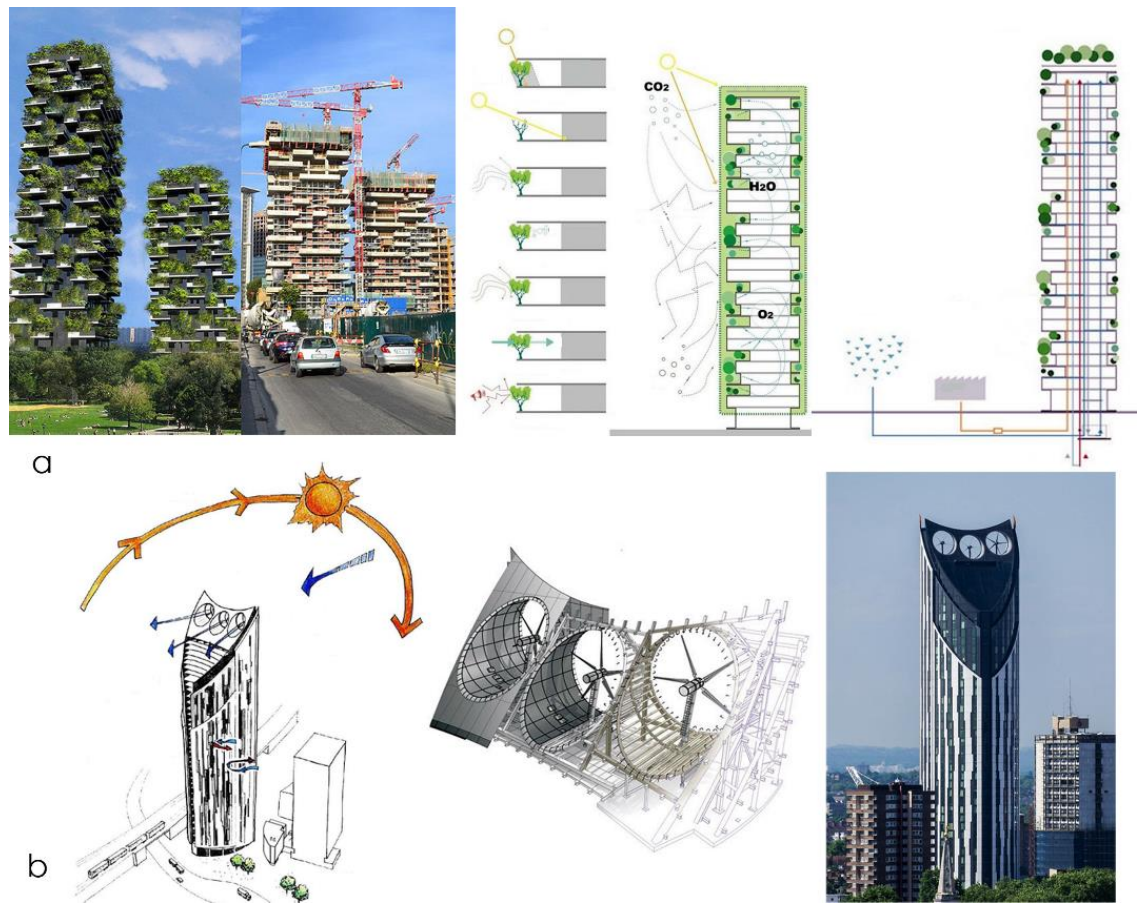

Fig. 3. Examples of buildings: a - Bosco Verticale, a residential complex, Milan, Italy. Authors: Stefano Boeri Architetti [28, 29], b - Strata Tower, a residential complex, London, Great Britain. Authors: BFLS [30].

The form of the building helps to cut lighting costs and reduces heat loss due to a smaller cladding area. Basement and roof spaces also contribute to the reduction of heat loss [30]. The roof space is occupied by three turbines, since the Strata Tower is the world's first building to integrate wind turbines in its design and architecture. The aerodynamics of the construction was designed to maximize wind power throughout the year. The turbines 
produce only 8 percent of the building's total energy consumption; for this reason, natural ventilation, heat recovery ventilation systems and high-performance insulating glass units are used to reduce heating and cooling costs. Heating is provided via boilers with low gas flow rate, while grey water is employed for toilet water supply. Thus, the building primarily aims at conserving its internal energy.

The Wuhan Greenland Center building (636 m, 131 stories, 2010-2018) has the shape of a triangle, the softly rounded corners of which are oriented towards the prevailing northeast, south-east and south-west winds (figure 4a). The building`s uniquely streamlined form makes a great contribution to wind load reduction [31]. In addition, apertures have been placed in the curtain wall to assist in venting wind pressure against the tower. Six basement floors and a mechanical floor in the upper level constitute 'buffer' zones and reduce the total heat loss. The building uses heat recovery ventilation, pretreated grey water for its evaporative cooling system, an automatic lighting system with low-energy-consuming lamps, and water-conserving low-flow plumbing fixtures (air balloons). Every detail of the building`s design is aimed at preserving internal energy and reducing carbon footprint.

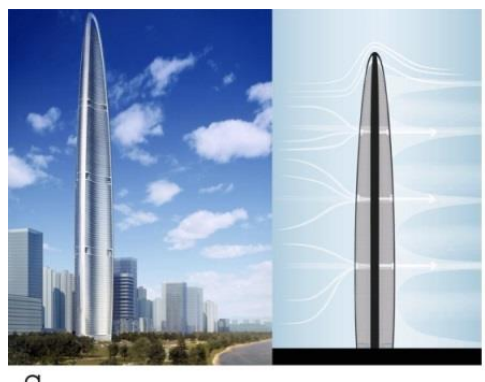

a
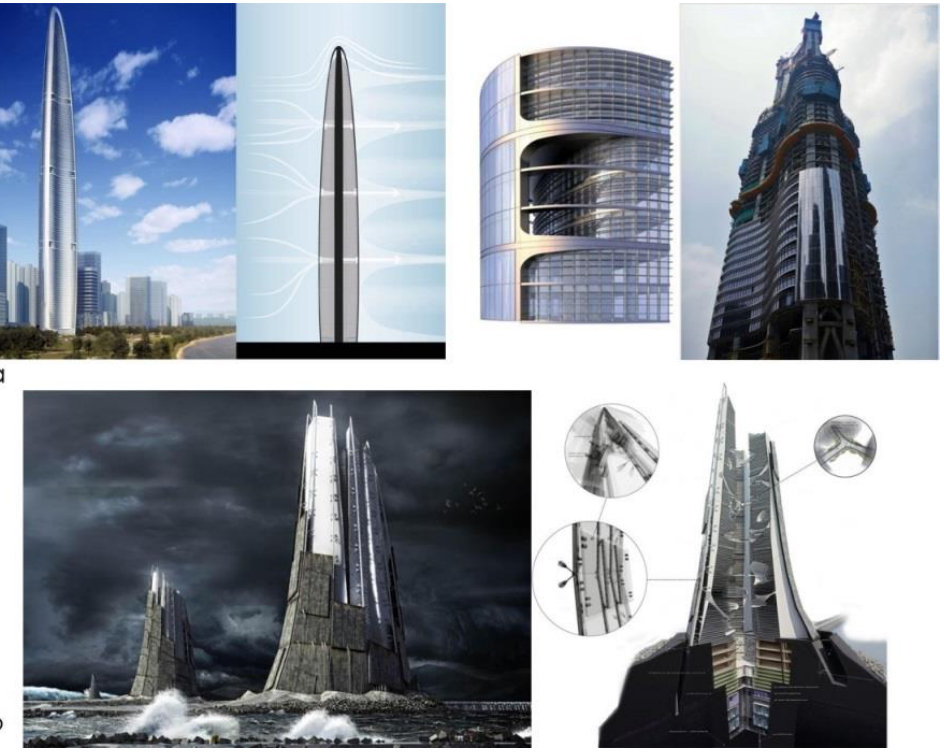

Fig. 4. Examples of buildings: a - Wuhan Greenland Center, a mixed-use complex, Wuhan, China. Authors: Adrian Smith + Gordon Gill Architecture [31], b - Citadel Skyscaper, a mixed-use complex, Japan. Authors: Victor Kopieikin, Pavlo Zabotin [32].

The Citadel Skyscaper (500 m, 2012) project was developed for the coastline of Japan, a country affected the most by natural disasters (figure $4 \mathrm{~b}$ ). The design is actually a symbiosis of a skyscraper and a bunker able to protect the inhabitants of the island against natural and anthropogenic influences [32]. Within the framework of the project, all functions of the urban environment are performed by autonomous towers installed in the sea. The citadels themselves are connected by the coastline and create a defensive shield functioning both above and below ground. It is proposed to locate the skyscrapers at a distance of $2-3 \mathrm{~km}$ from the shore. The towers will be able to withstand tsunami waves up to 50 meters. The foundation is planned to be laid at a depth of $1200 \mathrm{~m}$, while the height of the buildings will constitute $500 \mathrm{~m}$, with a guarantee of seismic stability. It is worth mentioning that the citadels are intended to be completely self-sustaining in terms of energy: tidal energy is planned to 
be used as the principal source of power, drinking water supply will be provided via boreholes, and food is planned to be stored in the basement floors.

\section{Discussion}

The examples considered above make it possible to speak about the successful implementation of modern energy-efficient technologies into high-rise construction. In this respect, alongside with traditional technologies used in low- and mid-rise buildings, new specific technologies are created that are characteristic of high-rise buildings and result from their design, massing and planning solutions. The range of technologies applied is wide and continues to develop.

Recent decades have witnessed the rapid development of energy efficient and alternative energy sources technologies, which continue to evolve and generate more and more concepts of energy efficient buildings with respect to the number of stories. Some ideas have already become a reality, while others remain on paper in the form of futuristic projects which will be realized in the near future. One can say with certainty that energy-efficiency issues are of vital importance today in relation to any construction. However, in the case of high-rises it commonly happens that not the technologies form a building, but rather a conceptual idea gives rise to technology. The key aspects of the projects include lower energy consumption and lesser environmental impact of high-rise construction and operation.

\section{Conclusions}

Energy efficient technologies introduce new forms and technological elements into architecture. Furthermore, new building materials continue to appear, and new compositional and artistic solutions have been found for façade silhouette and articulation. Apart from aesthetic and compositional interpretation of architectural forms, an architect nowadays has to address the task of finding a synthesis between technological and architectural solutions, which requires knowledge of advanced technologies. In this regard, an architect should collaborate with other specialists, conduct experiments and research, analyze the findings and choose such methods to improve energy efficiency (or the combination of such methods) that will meet the given parameters (aesthetic, ecological, energy-efficiency, etc.).

\section{References}

1. V. P. Generalov, The History of High-Rise Construction (Samara, 2011)

2. V. P. Generalov, The Characteristic Features of High-Rise Building Design (Samara, 2009)

3. V. Ivanov, I. Bakhtina, T. Ivanova, S. Ilinykh, Urban Construction and Architecture, 2, 88-93 (2015)

4. O. S. Popel, Energosvet, 5, 22-26 (2011)

5. T. Ya. Vavilova, N. D. Potienko, I. V. Zhdanova, Procedia engineering, 153, 938-943 (2016)

6. G. Sarkisian, Ya. Gorbatenko, Energy efficiency in Russia: hidden reserve (Moscow, Center for energy efficiency, 2009)

7. V. Generalov, E. Generalova, Urban Construction and Architecture, 4, 23-29 (2015)

8. G. V. Esaulov, Proceedings of TSUAB, Architecture and urban planning, 6, 9-24 (2014) 
9. A. N. Remizov, Sustainable Architecture: Present and Future, Proceedings International Symposium 17-18 November 2011, 40-50 (2012)

10. E.Yu. Vityuk, Architecton, 13, 45-50 (2010)

11. J. W. Lund, Design of closed-loop geothermal heat exchangers in the U.S. Course on geothermal heat pumps (2002)

12. H. Ehhorn, J. Reiss, H. Kluttig, R. Hellwig, AVOK, 2, 36 (2006)

13. B. Sanner, Ground Heat Sources for Heat Pumps (classification, characteristics, advantages) (2002)

14. N. V. Shilkin, Methods to improve the thermal efficiency of buildings and their economic evaluation: dissertation in support of candidature for a technical degree (Moscow, 2007)

15. G. P. Vasiliev, Heating and cooling of buildings using low-grade thermal energy of the surface layers of the Earth: dissertation in support of candidature for a technical degree (Moscow, 2006)

16. B. Kuwabara, T. Auer, T. Akerstream, G. Klym, M. Pauls, K. Opie, J. Peterson, Harnessing climate (High Performing Buildings, 2011)

17. V. Generalov, E. Generalova, Urban Construction and Architecture, 4, 32-38 (2015)

18. A. Yu. Zhigulina, Urban Construction and Architecture, 1, 29-30 (2011)

19. B. Holdsworth, Refocus, 6, 58-60 (2005)

20. P. Lotfabadi, Renewable and Sustainable Energy Reviews, 38, 285-295 (2014)

21. A. Wood, Rethinking the Skyscraper in the Ecological Age: Design Principles for a New High-Rise Vernacular, Proc. of the CTBUH 2014 Shanghai Conf. (2014)

22. P. Lotfabadi, H. Z. Alibaba, A. Arfaei, Renewable and Sustainable Energy Reviews, 57, 1337-1346 (2016)

23. URL: http://capitagreensingapore.com/green-features/ (last accessed 25.03. 2017)

24. URL: http://www.architectmagazine.com/design/buildings/edith-greenwendell-wyattfederal-building-designed-by-cutler-anderson-architects_o [electronic resource] (last accessed 12.04. 2017)

25. URL: http://www.theplan.it/eng/webzine/international-architecture/al-bahrtowers\#sthash.RcKFbuA9.dpbs (last accessed 02.04. 2017)

26. URL:http://www.ctbuh.org/TallBuildings/FeaturedTallBuildings/AlBaharTowersAbuD habi/tabid/3845/language/en-US/Default.aspx (last accessed 02.04. 2017)

27. URL: http://www.archdaily.com/44596/manitoba-hydro-kpmb-architects (last accessed 02.04. 2017)

28. URL: http://www.archdaily.com/777498/bosco-verticale-stefano-boeri-architetti (last accessed 02.04. 2017)

29. URL: http://archi.ru/projects/world/8818/zhiloi-kompleks-bosco-verticale (last accessed 02.04. 2017)

30. URL: https://www10.aeccafe.com/blogs/arch-showcase/2011/04/15/strata-se1-inelephant-castle-uk-by-bfls-architects/ (last accessed 02.04. 2017)

31. URL: https:/ecotechnica.com.ua/arkhitektura/992-wuhan-greenland-center-samyjvysokij-neboskreb-kitaya-budet-samym-energoeffektivnym.html (last accessed 02.04 . 2017)

32. URL: http://www.archdaily.com/221560/citadel-skyscraper-victor-kopeikin-pavlozabotin (last accessed 02.04. 2017) 